\title{
LAW AND THE THIN VENEER OF CIVILIZATION*
}

\author{
MR. JUSTICE W. G. MORROW**
}

\begin{abstract}
Mr. Justice Morrow employs his sympathetic understanding of the North and it's native inhabitants in a revealing discussion of the sudden, apparent metamorphosis which has occurred as a result of the recent advent of Canadian law and society in the Northwest Territories. The author contends that although the physical attributes of Canadian society have been effectively superimposed upon the native culture, the experience of the Northwest Territory Courts suggests that the effect is merely superficial. Although uniformity of Canadian law is desirable, Mr. Justice Morrow argues that it is difficult and perhaps meaningless to achieve such uniformity through the arbitrary application of laws and penalties which are foreign to time honored native customs and cultures.
\end{abstract}

The legal entity known as The Northwest Territories is that part of Canada north of the sixtieth parallel and east of the mountains which form the eastern boundary of the Yukon. This vast area of some $1,300,000$ square miles, almost one-third of Canada's land area, extends over to the western edge of Hudson Bay, and includes all of the islands in that Bay. It also takes in all of the Arctic Islands; and, if you accept what I said in my judgment in Regina v. Tootalik, ${ }^{1}$ it includes the off-shore ice, which of course extends to the North Pole.

Alberta and Saskatchewan before 1905 were a part of the Northwest Territories, as also was the Yukon prior to the gold rush. It is not unreasonable therefore for the residue of this great territory to now be commonly referred to as Canada's last frontier and indeed as one of the world's last frontiers.

The reader will, I think, understand my subject better if he pictures a vast northern empire relatively untouched and very sparsely populated. The total population is only 32,000 and almost two-thirds of these are native Eskimo or Indian people-for the most part scattered along the Mackenzie River and along the Arctic Coast, as well as on some of the Islands. A harsh topography combined with a cold climate, results in a hard and difficult way of life. While it has a great variety of animal, bird life and flora, the numbers are not as great as people in other parts of Canada commonly believe.

For example, I have been travelling throughout this area for eleven years now, flying at least 40,000 miles each year during the last four of these, and only last August did I see my first herd of musk-oxen. During the same period I have, many times over, covered areas where the polar bear are hunted, and as yet I have not seen one of these wonderful animals in the wild state.

It is only with the installation of DEW line sites after the war and the more recent exploration for minerals and oil and gas that Canadians as a whole, and the Canadian Government in particular, have begun to really show an interest in this area and in its people. This interest has of course been stimulated by people such as Farley

\footnotetext{
- Extract from Mr. Justice Morrow's 1970 Henry Marshall Tory Lecture.

* Judge of the Territorial Court of the Northwest Territories.

( (1970) 71 W.W.R. 455.
} 
Mowat who have written about the wonderful native people and of the hardships to which they have been subjected.

My predecessor, the Honourable J. H. Sissons, first Judge of the Territorial Court of the Northwest Territories, who assumed office in 1955, found that even at that date the North was really an undeveloped country and that certainly its Indian inhabitants and particularly the Eskimos were still almost untouched by what one may call civilization. In his day they were just beginning to emerge from what I choose to call a stone-age way of life, to change from a primitive culture, to become civilized. When I use this phrase "become civilized" I want to make it very clear that I do not mean to argue that what they are attempting to acquire or become, or what in some cases they are having forced upon them, is necessarily for the better.

Historically, these same native people have had contact with the white man for longer than Canada has been a nation. The contact of course goes back to the early days of the explorers. Martin Frobisher for example, was in contact with the Eskimo on Baffin Island in the Elizabethan days. The whalers had contact with the same people in Hudson Bay and in the Herschel Island areas well back in time, and of course in the early eighteen hundreds there was a complete transportation system crossing northern Canada from the Hudson Bay posts near Churchill to posts such as Ft. Simpson where the Liard River joins the Mackenzie. In those days one could send letters by dogsled or by canoe, depending on the season, across wilderness Canada with the assurance that they would be delivered.

It is important to remember that these contacts left the native people to pretty much live their own lives in the time-honoured way. They were introduced to firearms, metal tools and similar things but no real attempt was made to bring them into our way of life. As late as the 1950's therefore it was not unusual for the authorities to hear of instances of behaviour based on tribal custom that would not be tolerated today-infanticide, assaults that we would call rape, and some homicides. In rare cases one finds instances where prior to 1955 courts were sent in from the provinces to try murder cases but these were relatively infrequent.

Our national awareness of how the original northern inhabitants have been neglected, which has come in recent times, has brought about what might be called a crash program embracing new schools, nursing stations, itinerant courts, local Justices of the Peace, police posts and Government officials such as area administrators, welfare people, and so on, throughout the area.

If one were to make an extensive trip throughout the territory today, one would find that this crash program has resulted in change in almost every community. I do not propose to dwell on these changes in any great detail. My only purpose is to impress upon the reader that there has been tremendous change and this, if anything, is increasing in tempo with every passing year. In the average native community today one will, for the most part find frame houses, surprisingly well built, a Bay store carrying the same goods (without of course the variety) that one will find in the smaller centres of Alberta. Almost always there will be electric power, a nursing station and a wellequipped school. If one is looking for people in native costume, whether 
buckskin or caribou parka, one may be disappointed. A large proportion of the local inhabitants dress in the white man's garb. In fact, for the most part it is the white man in the community who tries to dress like a native-in furs.

The native people have made the physical changeover to the modern way of life in a very few years. The man who a few years ago knew only the dogsled and kayak is now well versed in skidoos and motorboats. All ages have become familiar with and used to what one may look upon as the normal accoutrements of the Twentieth Century way of life.

They have made these changes quickly and well. But have they really made the transition? I do not think that anyone such as myself can be too firm in this sphere. Certainly the superficial result is convincing. And I must emphasize my admiration for how these people have adjusted to and come to adopt the new way of life-while to some extent, at any rate, retaining some of the old. My own observation however is that they still have one foot in the door of the past. I do not think that the spiritual or the thought processes have made the changes that the physical changes or adaptations might lead one to expect. The experience of the Court would certainly suggest that even those large numbers of native people who are adherents to the Christian faith still retain a reverence for their old beliefs. Old taboos are still lurking in the background.

An Anglican Bishop who had spent many years in the North once described to me how pleased he was one day when a highly respected chief attended his service in a small northern community and asked for a blessing to ensure a good hunt. Later however he found out that the chief had already been to the father across the way for the same purpose and that he had also checked in with the medicine man. When the Bishop later asked him about it the chief replied that he did not want to take any chances.

No one today can be too sure just how much of this really goes on. I do know, however, that not infrequently this carry over of primitive beliefs, the primitive way of life, does show up in court and does appear to have an effect on the behaviour of the persons involved. Some years ago, for example, Mr. Justice Sissons had to adjourn a case because one of the important witnesses threw a fit while testifying. It was apparent that the accused, who was an Eskimo shaman, had successfully put a "whammy", as they call it, on the witness. The case could only be completed later by placing the accused in a position where he could not look directly at the witness.

Recently a case came before me which involved a young Eskimo girl, whose parents had been shamans in a central Arctic community. Because she was showing the same propensities as her parents, the authorities arranged to have her transferred to a different community and placed in a school run by a church organization. It was not long before she began to exert a disturbing influence over the other native students. These students all professed the Christian faith but nonetheless she exerted an influence over them. At the time she came before me on a theft charge I was placed in a real quandry as to what to do with her. In view of her background I did not think normal methods of punishment would be applicable. In the result I sent her 
to Alberta for psychiatric treatment but with a firm direction that it was to be by a psychiatrist who had experience with Eskimo people and that he was to work in conjunction with an anthropologist.

A few years ago a case came before Mr. Justice Sissons at Spence Bay. ${ }^{2}$ This small community in the Central Arctic has quite a reputation for witchcraft. What had happened in the present case was that a woman, wife of one of the hunters in a small encampment some two hundred miles north of Spence Bay, became mentally unbalanced. On two previous occasions she had shown these same symptoms but each time arrangements were made to take her to an Alberta mental hospital for attention. On the last occasion, however, these people were out of radio contact with the police or anyone else who could help. In addition the time of the year prevented going for help by boat or by dogsled. As a result these two Eskimo families, some dozen or more people, were isolated and forced to handle the problem on their own. The woman, as she became more and more unbalanced, professed to throw a curse on her companions. She threw fits, she tore up their tents, she destroyed their equipment and their boats.

At first the others tried to appease her and when that failed they tied her up and escaped to a nearby island. They were so busy trying to protect themselves that they were unable to hunt for food. As they watched her from a distance she was able to untie herself and began raging back and forth. Even her success in breaking free lent credence to her claims for supernatural powers. Finally in desperation the leaders decided she must be done away with. As they all said, "We know it is wrong by the white man's law, but we have our children and must not let them die." In the result, two young men, one of them her son, were delegated to kill her if she would not desist. Her son was chosen as one of them to avoid starting a vendetta within the group. She, of course, did not desist and so was shot. At the trial before a jury, at Spence Bay, the psychiatrists called as witnesses all agreed that it was not possible for these people, situated as they were, to attempt to live with a person in her then frame of mind. The witnesses said that white people in the same circumstances would have felt forced to do the same thing. In any event the jury brought in a verdict of manslaughter which satisfied the community and prevented a tragedy which would have resulted had the verdict been murder as the law demanded.

One never can tell to what degree this primitive background may be the reason for these people appearing before the court. With a communal way of life as the accepted thing for generation after generation and a tradition of sharing food and shelter, it is not always easy to punish them for stealing food or liquor or other things. Again when one realizes that in their traditional way of life it is an accepted fact that young people may get married before the age of fourteen years, just how meaningful is it to charge a man for having intercourse with a female under fourteen, the offence which we call statutory rape? In sentencing a healthy young Eskimo hunter for just such an offence at Rankin Inlet a few years ago, I can still remember the look on his face. He had never been told this was contrary to our law.

${ }^{2}$ R. v. Shooyook et al. (unreported, Northwest Territories Trial Division). 
Years ago Mr. Justice Sissons tried a young Eskimo for murder. He was accused of having assisted his father to commit suicide by loading the rifle and otherwise assisting in the positioning of the weapon so as to cause the death. At the trial evidence revealed that the custom of old people, when they become a burden on the community, was to do away with themselves in the interests of the wellbeing of the community. The boy in the present case was doing his father's bidding to make effective the time-honoured custom.

Such primitive customs, as we are wont to call them, have also brought the Eskimos into conflict with our laws in respect to marriage and adoption. In 1961 for example, a case came before the Court in which the Eskimo marriage by custom was attacked. ${ }^{3}$ An Eskimo named Noah had been burned to death in an industrial accident at Broughton Island. He was survived by a widow (married to him by custom marriage) and a son by her. The Government took the position that she was a concubine and that the insurance money should go to his brothers and sisters instead of to the widow and child. The Judge applied the common law of England and held that it recognized the ancient customs of the native people.

Again in the same year, In re Katie ${ }^{4}$ was tried. In this case the primitive custom of exchanging children for such practical reasons as one family having two boys and another two daughters, each of which should have a hunter and a sewer, was upheld on the same basis.

In the old Eskimo way of life it was not uncommon to keep the family down to a size that could be adequately fed and looked after. It was quite the usual thing to practice what in our law is infanticide. In 1960 an Eskimo mother killed her third child at birth because she could not look after it. She was practicing the time-honoured custom.

The law enforcement officers and the Courts in the north are often confronted with breaches of the Game Laws. When a people have always lived in a certain way, and one aspect of that is to shoot a polar bear when one sees it, shoot ducks before they fly south, and shoot caribou while they are abundant, it must be confusing to find oneself suddenly brought up before the law.

In the duck case, Sikyea v. Regina, ${ }^{5} \mathrm{Mr}$. Sikyea, an Indian near Yellowknife, eventually found himself before the Supreme Court of Canada, all because he had shot a duck out of season-something he and his predecessors had done since time immemorial. Even if anyone had told him that by treaty with the United States the ducks that he thought he could always shoot were now to be protected for sportsmen the length and breadth of America, he would not have understood.

And what about Mr. Tootalik, ${ }^{6}$ who with three others shot a female polar bear and two young bear, two of them with one shot? The Game Ordinance said one must not shoot a female polar bear with young. It did not say how one was to tell what was a young polar bear nor did it say how one could tell a female polar bear from a male bear. He and his friends did not think they were doing

\footnotetext{
3 Re Noah Estate (1961) 36 W.W.R. 577.

4 (1962) 38 W.W.R. 100.

[ [1964] S.C.R. 642.

- Supra, n. 1.
} 
anything wrong. They were merely hunting as they had always done. Fortunately, in this case Mr. Justice Maddison was able to acquit the hunters because of the confusing language of the game law.

All of these situations or confrontations, if you choose to call them that, do cause confusion and must make it difficult for these people to understand our law and custom. Recently a murder trial took place in Frobisher Bay where an accused had shot a man following what might be called a drunken argument. ${ }^{7}$ As the evidence unfolded at the hearing, one of the most tragic pictures imaginable emerged. Witness after witness established how this primitive, uneducated Eskimo, when the moon conditions were right, would have a spirit telling him it was now time to straighten things out with his people, he was now strong enough to do it, and he was to kill. In his mind he believed it and there was nothing to indicate that the other people around him disbelieved it. Add to this mental state an excess of liquor and one can imagine the volatile situation that cost one man his life. The wonder is that it was only one. This man broke our law but in his own mind he broke no law.

Let us examine a final specific example. In 1960 at Cambridge Bay an Eskimo hunter shot and killed a Mounted Policeman. ${ }^{8}$ This case is of some significance in illustrating the primitive situation in relation to our law. Firstly, the man had reached a mental state of depression, brought on by excessive drinking. In escaping from the police, he grabbed a rifle and one shell, not to kill anyone with but to commit suicide. In his words, he ran outside the police building onto the sea ice as he did not wish to cause a mess in the building. Unfortunately, the police constable and his corporal pressed after the man too quickly and too closely. As they yelled to him to stop he swung around with rifle at the hip and the gun went off. Down went one policeman, shot dead.

At the trial, the medical evidence was to the effect that in respect to primitive people such as this man, where the traditional occupation has been hunting, where recourse to knives and clubs and guns is normal, it is almost instinctive to act as in fact this man had acted. To quote from some of the medical evidence:

Q: Let us talk about inhibitions; the more highly a person has been trained, he is less likely to show the signs.... alcohol is less likely to affect him in the manner of a real poison, am I correct?

A: I think that's a fair statement, yes, I think those of us who have this what I called a while ago the veneer of civilization quite thoroughly indoctrinated in us, we, on the average, are going to lose those a little more slowly than some person who hasn't got them. Now it may be a person who hasn't got them, such a person will lose what he has no faster than we lose what we have. It is just a matter of us having more.

Q: I don't suppose you mean to say that the person would lose inhibitions that have been put into him in what we might call the primitive state?

A: No, he should hold on to those. The morals of his society he should hold on to just as strongly as we hold on to ours.

It appears to the writer, therefore, that although Canadians may insist on the law being uniform throughout Canada, particularly the criminal law, we must, if we are to be humane, and if we are to apply

? R. v. Moses (1969) 68 W.W.R. 509.

- R. v. Ayalik (1960) 33 W.W.R. 377. 
it in justice, remember that in respect to these people of the north some allowance must be made to compensate for their background, for the fact that they are just now emerging from one way of life, sometimes referred to as a stone age way of life, to our Twentieth Century.

Editor's note: The Edmonton Journal April 17, 1971, contains the following comment: The Territorial Court of the Northwest Territories made legal history here this week by selecting and trying a case before an all-Eskimo jury.

With Mr. Justice W. G. Morrow presiding, the court selected five men and one woman to hear evidence on a charge of rape against Joachim Kavik, also an Eskimo.

Since 1955, when the territorial court came into being, there have been numerous Eskimos selected for jury duty, but never before have the natives of an Eskimo community been asked to sit in judgment of one of their own without a white to influence them.

Mr. Justice Morrow called it "a first in Canada, if not North America" and told the jury that they were "making history."

"This is the first time in the history of Canada and perhaps of North America, that an all Eskimo jury has been chosen to try an Eskimo," he said. "It puts quite a burden on you, but it demonstrates the effort that is being made to place justice in your hands... it is only right that you should try your own cases...." The case against Joachim Kavik-charged with the rape of a seventeen year-old girl last June, lasted two and a half days and ended with an acquittal. 